
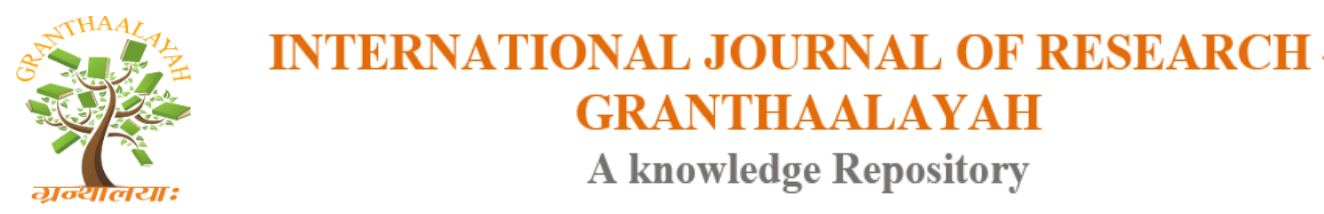

Science

\title{
OBSERVED SHIFT AND MERGE OF HYDROLOGICAL REGIMES IN THE SOTA CATCHMENT, BENIN; AN EVIDENCE OF CLIMATE CHANGE
}

\author{
Oyerinde G. T. *1, Olowookere B.T. ${ }^{1}$ \\ ${ }^{* 1}$ Department of Soil Science, Faculty of Agriculture, University of Abuja
}

\begin{abstract}
Sub-Saharan Africa have low resilience capacities to the challenges of climate change. This study is aimed at assessing climate trends and regime shifts at the Sota Catchment, Benin. Long term rainfall and river discharge were analyzed from 1950-2010 in order to generate patterns of changes in the basin. Analysis of the hydro-meteorological were based on the two prominent vegetation zones (Sudan and Guinea Savannah) in the catchment. The rainfall and discharge data were subjected to regime shift analysis and Standardized Precipitation Indices (SPI) were computed. Downward trend of precipitation was observed in the Guinea and Sudan vegetation zones of the catchments from 1970. Rainfall and runoff amount at the two assessed vegetation zones was different in the Guinea and Sudan zone up till 1970. Clear merge of rainfall and runoff amount and patterns was witnessed between the two vegetation zones at 2007. This calls for attention of scientists and policy makers in the region to deploy necessary adaptation measures based on such clear evidence of climate change.
\end{abstract}

Keywords: Climate Change; Rainfall; Runoff; West Africa; Climate Variability.

Cite This Article: Oyerinde G. T., and Olowookere B.T. (2018). "OBSERVED SHIFT AND MERGE OF HYDROLOGICAL REGIMES IN THE SOTA CATCHMENT, BENIN; AN EVIDENCE OF CLIMATE CHANGE." International Journal of Research - Granthaalayah, 6(6), 205-211. https://doi.org/10.29121/granthaalayah.v6.i6.2018.1367.

\section{Introduction}

Climate change refers to a change in the state of the climate that can be identified (e.g. using statistical tests) by changes in the mean and/or the variability of its properties, which persists for an extended period, typically decades or longer (IPCC, 2014a). Renewable freshwater resources in west Africa have been shown by several authors to be highly vulnerable and strongly affected by climate change (Djigbo Félicien Badou, Kapangaziwiri, Diekkrüger, Hounkpè, \& Afouda, 2016; IPCC, 2007, 2014b; Oyerinde et al., 2015; Oyerinde, Lawin, \& Odofin, 2017; Sylla et al., 2015). Rising global temperature is expected to enhance the intensification of the hydrological cycle, resulting in more moisture being released into the atmosphere than the amount received by the soil (Diasso \& Abiodun, 2017; IPCC, 2014b). This will lead to soil water deficit, severer dry 
seasons and subsequently heightened risks of drought. Changing climate will also have significant impacts on the availability and accessibility of water in west Africa.

Sota basin domiciled in the Niger River Basin has experienced high variability in rainfall and runoff patterns. Global warming has induced hybrid rainfall (mixed dry and wet features) patterns in the basin (Djigbo Félicien Badou et al., 2016; Oyerinde et al., 2015, 2017; Salack et al., 2016). Transient recovery in rainfall from the drought period of 1970-1980 have been experienced in and around the basin in recent decades (Djigbo Félicien Badou et al., 2016; Oyerinde et al., 2015, 2017). Salack et al., (2016) described the hybrid rainfall to be characterized by false start and early cessation of rainy seasons, increased frequency of intense daily rainfall, increasing number of hot nights and warm days. High intensity rainfall coupled with land use changes have increased flash floods experienced from August to September along the river Niger coast and the Sota catchment (Amogu et al., 2010; Descroix et al., 2018). Badou et al., (2018) reported decrease in Blue Water (Stream flow) resources in Northern Benin which includes the Sota Basin. This will lead to increase in water stress impacts that is already a nagging challenge in the Sota Basin (Oyerinde et al., 2015, 2017). This study aims at adding additional information to precipitation and runoff patterns in the Sota basin by evaluating shifts and merge in rainfall and runoff patterns in the Sota's vegetation zones.

\section{Objectives}

- Assessments of precipitation and runoff trends in the Sota basin

- Evaluation of shift and merge of precipitation signals in the vegetations zones of the basin.

\section{Materials and Methods}

\section{Study Area}

The River Niger is third longest river in Africa after the Nile and Congo river. The river basin covers $7.5 \%$ of the African continent and it's the major water source for most country in the Sahel. The Sota is a catchment of the Niger basin located in Northern Benin (Fig 1). Sota takes source from eastern slopes of sandstone plateau Kalale which is over $400 \mathrm{~m}$ above sea level (Djigbo Félicien Badou et al., 2016). It is $254 \mathrm{~km}$ long with a catchment area of 13,360 km2. It has sandstone formations and the hydrographic network is very dense. The Basin of Sota is endowed with forests and gallery forests $(0.17 \%)$, woody savannah $(8.35 \%)$, savannas and shrublands (43.50), cultivated and fallow $(47.25 \%)$, grassland $(0.18 \%)$, plantation $(0.05 \%)$, water $(0.15 \%)$, Built up area (0.35\%) (Djigbo Félicien Badou et al., 2016). The main economic activities of local populations in the basin are: slash and burn agriculture, livestock, fishing and forest logging. Climate of the basin is tropical with a unimodal rainfall. Average annual rainfall amounts range from $700 \mathrm{~mm}$ (Sudan savannah) to $1000 \mathrm{~mm}$ (Guinea savannah). Monthly average temperature varies between $24.89^{\circ} \mathrm{C}$ and $32.48^{\circ} \mathrm{C}$, while the annual average revolves around $27.90{ }^{\circ} \mathrm{C}$ (Djigbo Félicien Badou et al., 2016). 


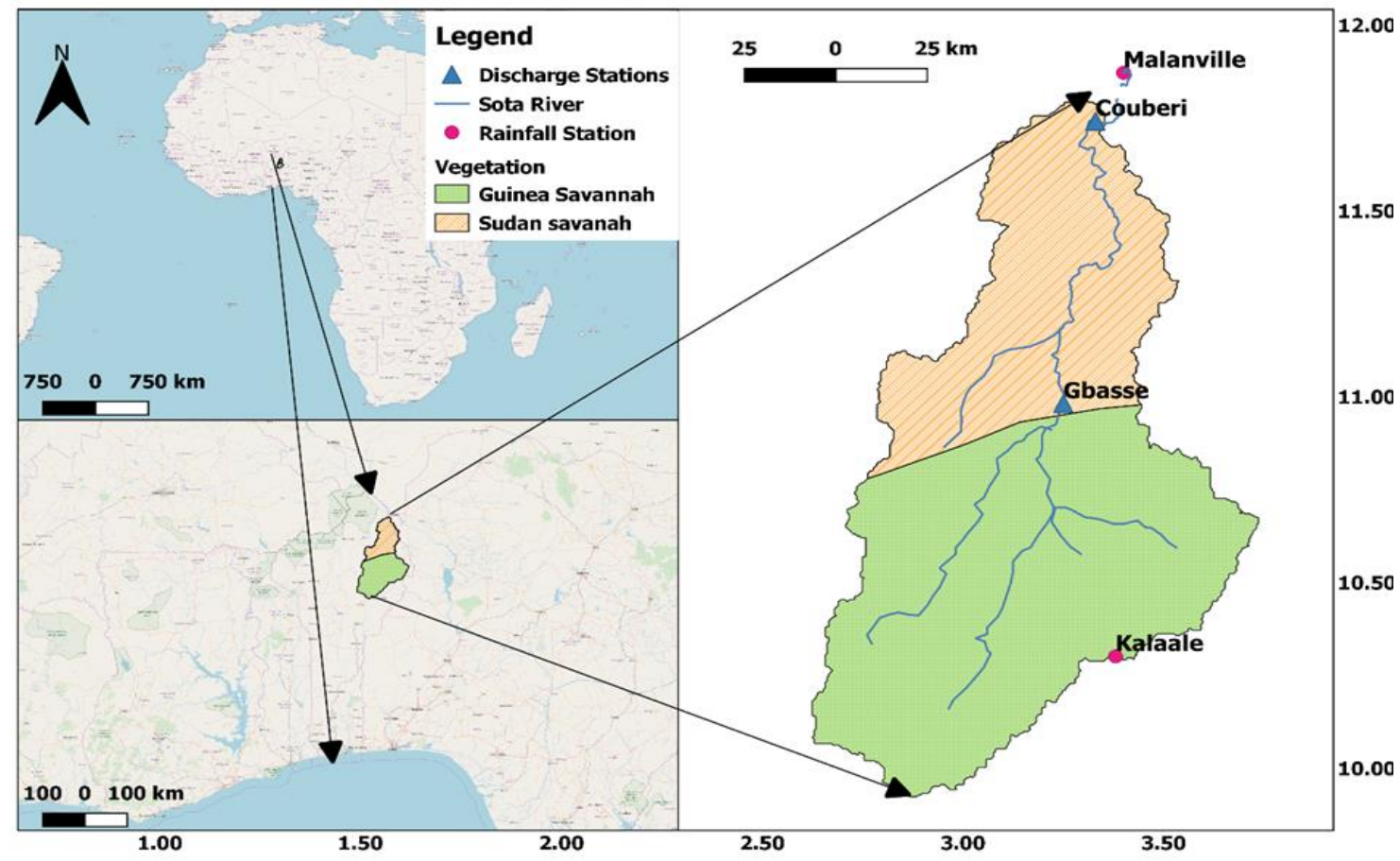

Figure 1: Map of Sota Basin

\section{Data Collection and Analysis}

Climate data collected were daily precipitation $(\mathrm{mm})$ and river discharge $(\mathrm{m} 3 / \mathrm{s})$ that is recorded at the Stations of the Benin Meteorological and Hydrological Services located in the Sota basin (Fig. 1). The data were collected from 1950 to 2010 in order to unveil long term fluctuations in climatic trends of the region. The data were subjected to the following analysis procedures:

\section{Hydrological Variability}

Inter annual rainfall variability was evaluated in the catchments with the Standardized precipitation index (SPI) (Ali \& Lebel, 2009; Mckee, Doesken, \& Kleist, 1993) described below:

$$
S P I_{i}=\frac{x_{i}-\text { mean }}{S_{x}}
$$

Where $\mathrm{x} \_$iand $\mathrm{S} \_\mathrm{x}$ are annual mean for year $\mathrm{i}$ and Standard deviation of the precipitation series respectively.

SPI computed was interpreted with the scale of Mckee et al., (1993) (Table 1). Flow regimes or hydrographs (a graph of water level with time) was plotted for the basin for the following time slice; 1951-1970, 1971-1990 and 1991-2010 in-order to fit available discharge data.

\section{Rainfall Regime Shift}

The sequential method (Oyerinde et al., 2015; Rodionov, 2004) was used for detecting significant regime shifts in the mean of precipitation in the catchments using cut-off length of 10 and 1 as Huber's Parameter. A regime shift occurs when a statistically significant difference exists between 
the mean value of the variable before and after a certain point based on the t-test. Trend lines of significant climate trends and merge of climate regimes were illustrated graphically.

Table 1: Classification and evaluation of different standardized precipitation indices (SPI) according to Mckee et al., (1993)

\begin{tabular}{|l|l|}
\hline SPI Value & Category \\
\hline$\geq 2.00$ & Extremely wet \\
\hline 1.5 to 1.99 & Severely wet \\
\hline 1.00 to 1.49 & Moderately wet \\
\hline-0.99 to 0.99 & Near Normal \\
\hline-1.00 to 1.49 & Moderately dry \\
\hline-1.50 to -1.99 & Severely dry \\
\hline$\leq-2.00$ & Extremely dry \\
\hline
\end{tabular}

\section{Results and Discussions}

\section{Rainfall Variability}

Sudan parts of the Sota basin showed gradual transition from severely wet years in the 1950s to near normal years in the 1960s after which it moved from moderately to extremely dry years from 1970-1973 (Fig 2). This dry trend continued in the northern parts up till 2007 after which we had an increase in rainfall to near normal. SPI in the Guinea region of the basin followed the same observed pattern in the north. The index moved from moderately wet years in the 1950s and 1960s then near normal dry years was observed in the early 1970s and this moved to extremely dry years in the late 1970s to early 1980s. A transient extreme wetness was observed in the beginning and the end of the 1990s; however, the same trend of normal dry years was showcased in other periods of the decade. This transient wetness finally moves into moderately dry years in 1999/2000 and continued till 2010.

\Kalale SPI (Guinea) 曰 BMalanville SPI (Sudan)

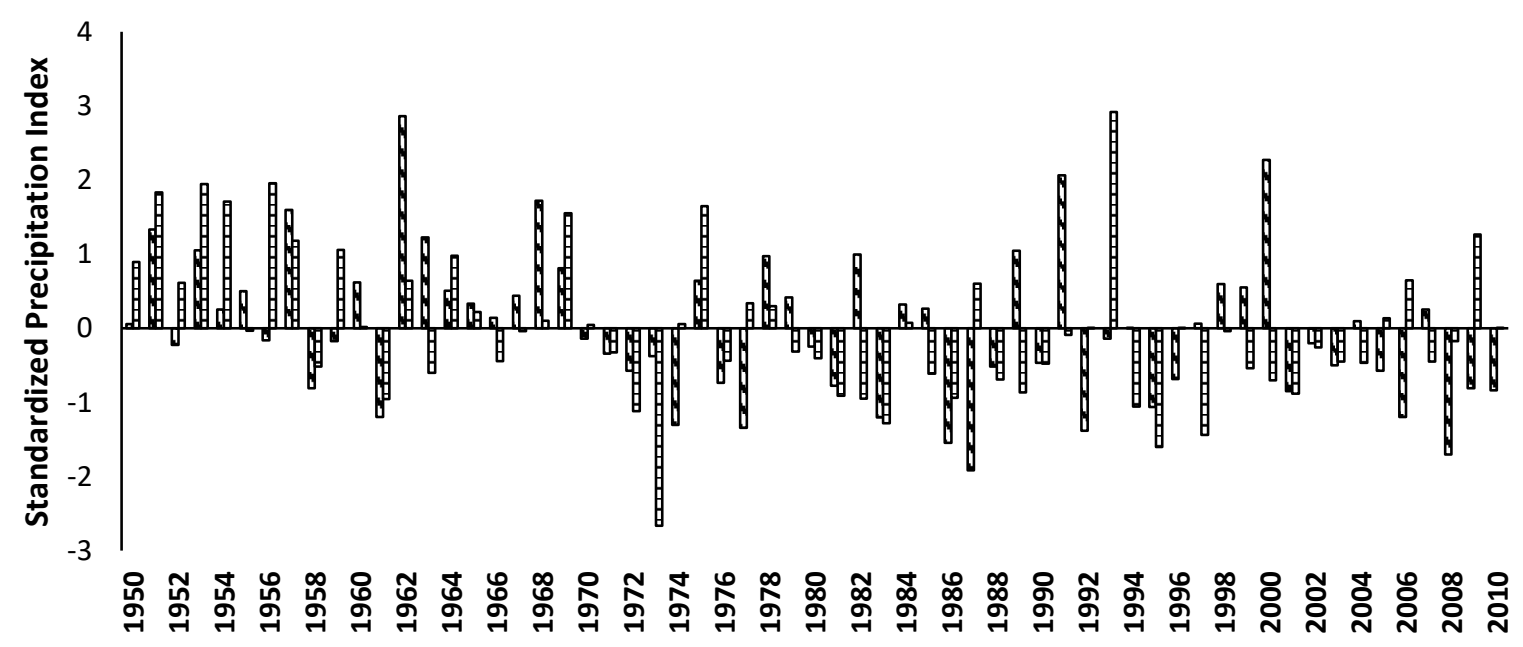

Figure 2: Comparison of Rainfall variability (SPI) at Kalale (Guinea) and Malanville (Sudan) vegetation zones of the Sota basin 


\section{Rainfall Regime Shifts}

Sudan region of the Sota significantly shifted $(\mathrm{p}<0.05)$ into deficit rainfall in 1959 which make it most vulnerable to drought in the Basin (Fig 3). This dry climatic regime has extended up till 2007 after which a slight upward shift $(\mathrm{p}<0.05)$ was observed. In contrast, a significant dry climate regime shifts $(\mathrm{p}<0.05)$ was only observed in 2007 in the Guinea region of the basin.

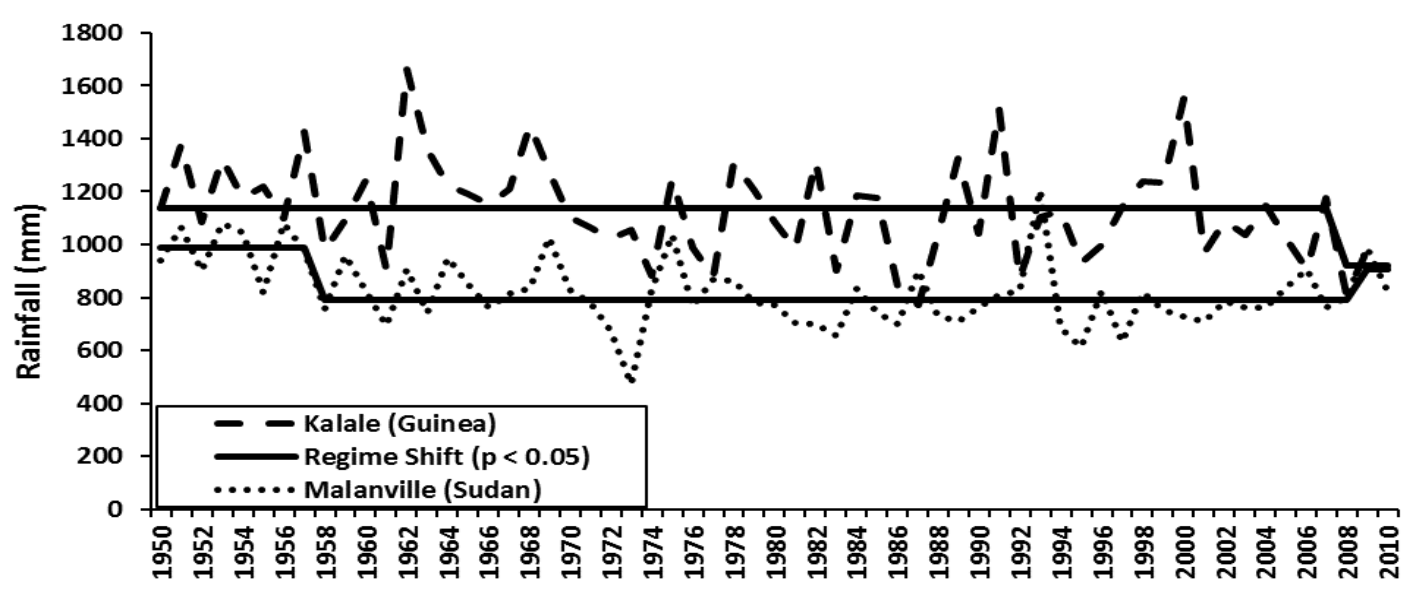

Figure 3: Significant regime shifts in rainfall at Kalale (Guinea) and Malanville (Sudan) vegetation zones of the Sota basin.

\section{River Discharge Evolution}

Fig 4 present patterns of river discharge at the Sudan and Guinea region of the Sota catchment. During the period of 1951-1970, there was clear distinction between flow amount at the Couberi and Gbasse hydrological stations. However, from 1970-1990 to the most current evaluated time slice (1991-2010), Flow regimes in the two vegetation zones and hydrological stations follow similar patterns in amount and seasonality.

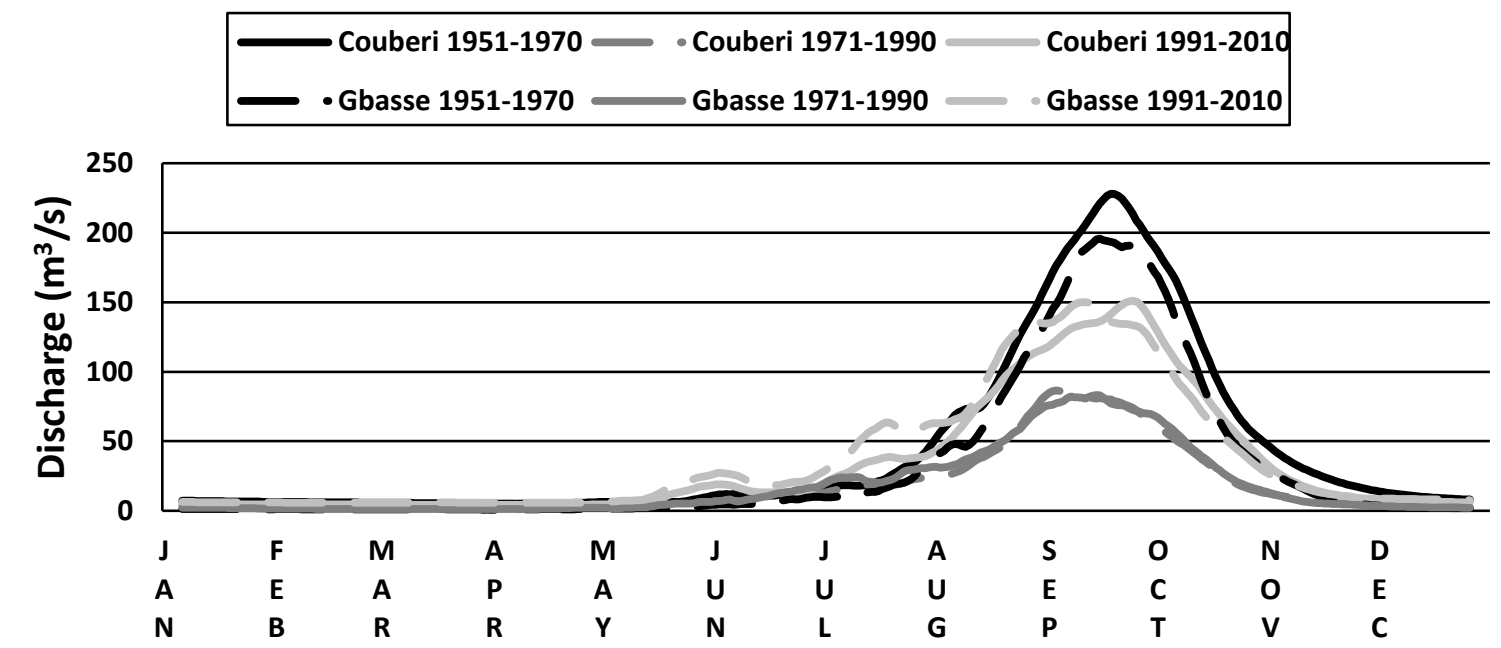

Figure 4: Comparison of runoff regimes from 1950-2010 at Gbasse (Guinea) and Couberi

(Sudan) hydrological stations of the Sota basin 
High inter annual rainfall variability was observed in the sub basins with clear differences in observed signals in different vegetation zones. Sudan zone with higher latitudes were characterized by lower rainfall which made them to be highly susceptible to drought while lower latitudes experience higher rainfall. This follows the pattern of rainfall distribution in West Africa which is as a result of the back and forth movement of the Inter Tropical Convergence Zone in the region (Lucio et al., 2012). The movement of the ITCZ follows the position of maximum surface heating associated with meridional displacement of the overhead position of the sun, near-equatorial regions experience two rain seasons, whereas regions further poleward experience one distinct rainfall season(Lucio et al., 2012; Oyerinde et al., 2015). The clear dry trends observed across the basins in 1970s and 1980s might be as results of about 150 to $250 \mathrm{~km}$ southward shift in isohyet lines observed in the whole Niger Basin which was attributed to global climate change (Inger, Ousmane, Martha, \& Jean-Claude, 2005).

Experienced transient recovery of rainfall from drought years from 2007 was due to reported hybrid rainfall pattern in the Sahel region (Salack et al., 2016). This type of rainfall is characterized by some attributes of wet and dry years with high interannual variability (Salack et al., 2016). Climate regime shift revealed general downward trend in the Guinea and Sudan region which was due to the effects of the west African drought at the period. The role of human activities such as deforestation have also been aggravating effects of the drought on local populations (Amogu et al., 2010; Descroix et al., 2018). Merge of hydrological regimes as showcased in similar hydrological signals been witnessed in two distinct vegetation zones of west Africa shows some impacts of unsustainable Land use change in the regions (Descroix et al., 2018) and man-made desert encroachments. This is also responsible for the observed deficit in river discharge revealed in the multi-decadal river discharge analysis and was in line with previous studies in the region (Djigbo Félicien Badou et al., 2016; Oyerinde et al., 2017).

\section{Acknowledgements}

Benin Meteorological and Hydrological Services are appreciated for providing the hydrometeorological data used in the study

\section{References}

[1] Ali, A., \& Lebel, T. (2009). The Sahelian standardized rainfall index revisited. International Journal of Climatology, 29(12), 1705-1714. https://doi.org/10.1002/joc

[2] Amogu, O., Descroix, L., Yéro, K. S., Le Breton, E., Mamadou, I., Ali, A., ... Belleudy, P. (2010). Increasing River Flows in the Sahel? Water, 2, 170-199. https://doi.org/10.3390/w2020170

[3] Badou, D. F., Diekkrüger, B., KapangaziwirI, E., Mbaye, M. L., Yira, Y., Lawin, A. E., ... Afouda, A. (2018). Modelling blue and green water availability under climate change in the Beninese Basin of the Niger River Basin, West Africa. Hydrological Processes. https://doi.org/https://doi.org/10.1002/hyp.13153

[4] Badou, D. F., Kapangaziwiri, E., Diekkrüger, B., Hounkpè, J., \& Afouda, A. (2016). Evaluation of recent hydro-climatic changes in four tributaries of the Niger River Basin (West Africa). Hydrological Sciences Journal, 62(5), 1-14. https://doi.org/10.1080/02626667.2016.1250898

[5] Descroix, L., Guichard, F., Grippa, M., Lambert, L., Panthou, G., Mahé, G., ... Paturel, J.-E. (2018). Evolution of Surface Hydrology in the Sahelo-Sudanian Strip: An Updated Review. Water, 10(6), 748. https://doi.org/10.3390/w10060748 
[6] Diasso, U., \& Abiodun, B. J. (2017). Future impacts of global warming and reforestation on drought patterns over West Africa. Theoretical and Applied Climatology, (November), 1-16. https://doi.org/10.1007/s00704-017-2209-3

[7] Inger, A., Ousmane, D., Martha, J.-H., \& Jean-Claude, O. (2005). The Niger River Basin : A Vision for Sustainable Management. (K. G. Golitzen, Ed.). The World Bank. https://doi.org/10.1596/9780-8213-6203-7

[8] IPCC. (2007). Summary for Policymakers. In S. Solomon, D. Qin, M. Manning, Z. Chen, M. L. Parry, O. F. Canziani, ... D. Martino (Eds.), Climate Change 2007: Mitigation. Contribution of Working Group III to the Fourth Assessment Report of the Intergovernmental Panel on Climate Change (pp. 7-22). Cambridge University Press. https://doi.org/10.2134/jeq2008.0015br

[9] IPCC. (2014a). Annex II: Glossary [Mach, K.J., S. Planton and C. von Stechow (eds.)]. In: Climate Change 2014: Synthesis Report. Contribution of Working Groups I, II and III to the Fifth Assessment Report of the Intergovernmental Panel on Climate Change. IPCC, Geneva, Switzerland.

[10] IPCC. (2014b). Summary for policymakers. In C. B. Field, V. R. Barros, D. J. Dokken, K. J. Mach, M. D. Mastrandrea, T. E. Bilir, ... L. L. White (Eds.), Climate Change 2014:Impacts, Adaptation, and Vulnerability. Part A: Global and Sectoral Aspects. Contribution of Working Group II to the Fifth Assessment Report of the Intergovernmental Panel on Climate Change (pp. 1-32). Cambridge University Press, Cambridge, United Kingdom and New York, NY, USA.

[11] Lucio, P., Molion, L., Valadão, C., Conde, F., Ramos, A., \& MLD, M. (2012). Dynamical outlines of the rainfall variability and the ITCZ role over the West Sahel. Atmospheric and Climate Sciences, 2(July), 337-350. Retrieved from http://www.scirp.org/Journal/PaperInformation.aspx?paperID=21400

[12] Mckee, T. B., Doesken, N. J., \& Kleist, J. (1993). The relationship of drought frequency and duration to time scales. Water, 179(January), 17-22. Retrieved from http://ccc.atmos.colostate.edu/relationshipofdroughtfrequency.pdf

[13] Oyerinde, G. T., Hountondji, F. C. C., Wisser, D., Diekkrüger, B., Lawin, A. E., Odofin, A. J., \& Afouda, A. (2015). Hydro-climatic changes in the Niger basin and consistency of local perceptions. Regional Environmental Change, 15(8), 1627-1637. https://doi.org/10.1007/s10113-014-0716-7

[14] Oyerinde, G. T., Lawin, E. A., \& Odofin, A. J. (2017). Farmers' Responses to Changing Hydrological Trends in the Niger Basin Parts of Benin. Hydrology, 4(4), 52. https://doi.org/10.3390/hydrology4040052

[15] Rodionov, S. N. (2004). A sequential algorithm for testing climate regime shifts. Geophysical Research Letters, 31(9), L09204. https://doi.org/10.1029/2004GL019448

[16] Salack, S., Klein, C., Giannini, A., Sarr, B., Worou, O. N., Belko, N., ... Kunstman, H. (2016). Global warming induced hybrid rainy seasons in the Sahel. Environmental Research Letters, 11(10). https://doi.org/10.1088/1748-9326/11/10/104008

[17] Sylla, M. B., Giorgi, F., Pal, J. S., Gibba, P., Kebe, I., \& Nikiema, M. (2015). Projected Changes in the Annual Cycle of High Intensity Precipitation Events over West Africa for the Late 21st Century. Journal of Climate, (April 2016), 150522112645005. https://doi.org/10.1175/JCLI-D-1400854.1

\footnotetext{
*Corresponding author.

E-mail address: ganiyuoyerinde@ yahoo.com
} 